DOI: https://doi.org/10.15407/techned2018.06 $: \underline{042}$

\title{
SIMULATION OF INDUCTION MACHINES WITH COMMON SOLID ROTOR
}

Journal

Publisher

ISSN

Issue

Pages
Tekhnichna elektrodynamika

Institute of Electrodynamics National Academy of Science of Ukraine 1607-7970 (print), 2218-1903 (online)

No 6, 2018 (November/December)

$42-45$

\section{Authors}

\section{Zablodskiy ${ }^{1 *}$, V. Pliuhin ${ }^{2 \star \star}$, R. Chuenko ${ }^{1 * \star *}$}

1 - National University of Life and Environmental Sciences of Ukraine,

15, Heroiv Oborony Str., Kyiv, 03041, Ukraine,

e-mail: zablodskiynn@gmail.com ; roman_chuenko@ukr.net

2 - O.M. Beketov National University of Urban Economy in Kharkiv,

17, Marshal Bazhanov Str., Kharkiv, 61002, Ukraine,

e-mail: vladyslav.pliuhin@kname.edu.ua

* ORCID ID : http://orcid.org/0000-0001-8889-8158

** ORCID ID : http://orcid.org/0000-0003-4056-9771

*** ORCID ID : http://orcid.org/0000-0002-9339-9764

\section{Abstract}

A simulation model is developed and transient modes of a double-module induction machine with a common external solid rotor are researched. It is established, that with the counter rotation of magnetic fields, a gearless mode of the steady operation of a double-module induction machine is provided at low rotational speeds of the solid hollow rotor, combined with a screw actuator. References 14, figure 1, table 1. 
Key words: simulation model, induction machine, solid rotor, transient mode.

Received: 05.03 .2018

Accepted: 24.04 .2018

Published: 23.10 .2018

\section{References}

1. Kim K.K., Ivanov S.N. On the problem of determining speed-torque characteristics of thermal electromechanical converters. Russian Electrical Engineering. 2009. No. 80. Pp. 459-465. (Rus)

2. Zablodskiy N., Plyugin V., Gritsyuk V. Polyfunctional electromechanical energy transformers for technological purposes. Russian Electrical Engineering. 2016. No 87(3). Pp. 140-144. (Rus) 3. Szczygiel M., Kluszczynski K. Rotary-linear induction motor based on the standard 3-phase squirrel cage induction motor-constructional and technological features. Czasopismo Techniczne. Elektrotechnika . 2016. No 112. Pp. 395-406.

4. Amiri E., Jagiela M., Dobzhanski O., Mendrela E. Modeling dynamic end effects in rotary armature of rotary-linear induction motor. Proceedings of IEEE Electric Machines \& Drives Conference (IEMDC). 2013. Pp. 1088-1091.

5. Alwash J.H., Qaseer L.J. Three-dimension finite element analysis of a helical motion induction motor. ACES. 2010. Vol. 25. No 8. Pp. 703-712.

6. Zhao J., Xinhui L., Xin Z., Han Y. Research on the energy-saving technology of concrete mixer trucks. Proceedings of IV IEEE Conference on Industrial Electronics and Applications. 2009. Pp. $3551-3554$.

7. Popovych O.M., Golovan I.V. Determination of equivalent circuit parameters of the induction motor and non-linear functions for field analysis results. Pratsi Instytutu Elektrodynamiky Natsionalnoi Akademii Nauk Ukrainy 2012. No 31. Pp. 38-48. (Rus)

8. Deshpande M.V. Electrical machines. New Delhi: PHI, 2011. 430 p. (Rus)

9. Kucevalov V.M. Questions of the theory and calculation of asynchronous machines with solid rotors. M.-L.: Energy, 1966. 302 p. (Rus) 
10. Zablodskii N., Pliugin V.,Lettl J., Fligl S. Dynamic Simulation of the Double-Stator Induction Electromechanical Converter with Ferromagnetic Rotor. Power Engineering. 2013. Pp. 1448 1453. (Rus)

11. Kopylov I.P. Mathematical modeling of electric machines. Moskva: Vysshaia Shkola, 2001. 327 p. (Rus)

12. Chornii O.P., Lugovoi A.V., Rodkin D.Y., Sysiuk G.Yu., Sadovoi O.V. Modelling of electromechanical systems. Kremenchuk, 2001. 410 p. (Rus)

13. Zablodskii N.N., Pliugin V.E., Skryl V.V. Problems of simulation and design of double-module EMPE with solid rotor. Visnyk NTU KhPI. 2013. No 51. Pp. 20 - 27. (Rus)

14. Sen S.K. Principles Of Electrical Machine Design With Computer Programs. Oxford: IBH Publishing Company Pvt. Limited, 2006. 415 p.

$\underline{\text { PDF }}$ 